\title{
Usaha Mikro Kecil dan Menengah JAKPRENEUR Meningkatkan Kelas Melalui Kepuasan Pelanggan
}

\author{
JAKPRENEUR's Small and Medium-Sized Micro Enterprises Increase \\ Class Through Customer Satisfaction
}

Oleh:

Siti Mahmudah'); Muhamad Asari' ${ }^{2)}$

"Sekolah Tinggi Ilmu Ekonomi IPWI Jakarta" 1,2)

idajpram@yahoo.com¹); Rafi1504@yahoo.com²)

\begin{abstract}
ABSTRAK
Penelitian ini bertujuan untuk mengetahui Kepuasan Pelanggan JAKPRENEUR di Kecamatan Cipayung dengan menganalisis Kualitas Produk, Kemasan dan Promosi. Penelitian ini menggunakan metode Statistic Package for Social Sciences (SPSS) dengan jumlah responden 104 orang Pelanggan JAKPRENEUR di Kecamatan Cipayung Jakarta Timur. Hasil penelitiannya bahwa pengaruh Kualitas Produk, Kemasan, Promosi terhadap Kepuasan Pelanggan positif signifikan.
\end{abstract}

Kata Kunci: Kualitas Produk, Kemasan, Promosi, Kepuasan Pelanggan JAKPRENEUR

\begin{abstract}
This study aims to find out JAKPRENEUR Customer Satisfaction in Cipayung Sub-district by analyzing Product Quality, Packaging and Promotion. This study used Statistic Package for Social Sciences (SPSS) method with 104 jakpreneur customers in Cipayung Sub-district, East Jakarta. The results of his research that the influence of Product Quality, Packaging, Promotion on Customer Satisfaction is positif significant.
\end{abstract}

Keywords: Product Quality, Packaging, Promotion, JAKPRENEUR Customer Satisfaction

\section{PENDAHULUAN}

Setiap orang memiliki target, impian yang hendak dicapai sampai titik mana, maka ia akan terus memperjuangkannya. Demikian juga para wirausaha JAKPRENEUR Kecamatan Cipayung Jakarta Timur yang terus bersemangat untuk meningkatkan kualitas produknya. Upaya yang dilakukan adalah dengan membangun kualitas produk yang lebih baik dengan terus mengembangkan inovasi agar cita rasa, nilai-nilai dapat dimanfaatkan dan dirasakan oleh konsumen dengan puas. Selain itu wirausaha JAKPRENEUR Kecamatan Cipayung Jakarta Timur terus berupaya mewujudkan produk yang dapat diterima oleh masyarakat. Produk mereka beraneka dan tentunya memiliki kekhasan tersendiri. Dengan berkomitmen membangun kepuasan pelanggan, tentunya wirausaha akan terus meningkatkan kualitas produknya disertai 
kemasan dan promosi yang terus menerus ke berbagai media. Berbicara Wirausaha JAKPRENEUR memang menarik karena di dalamnya berbagai pergulatan wirausaha dalam mengembangkan bisnisnya agar naik kelas. Penelitian wirausaha JAKPRENEUR belum banyak dilakukan oleh peneliti-peneliti sebelumnya. Diharapkan penelitian ini menjadi pembuka bahwa sudah saatnya wirausaha JAKPRENEUR naik kelas dengan memberikan pelayanan kepada konsumen secara memuaskan dari berbagai aspek. Kepuasan pelanggan harus menjadi skala prioritas sehingga akan menjadi pelanggan yang 'repeat order" sehingga mampu mendongkrak pemasukan bagi wirausaha.

Kepuasan pelanggan menjadi skala prioritas bagi wirausaha sehingga mampu meningkatkan kinerja usahanya dengan baik untuk setiap bulannya. Hal ini harus disadari bahwa wirausaha JAKPRENEUR Kecamatan Cipayung Jakarta Timur harus terus berkelanjutan dalam usahanya sehingga harus memberikan kepuasan pelanggan sampai produknya naik kelas. Dengan kinerja usaha yang jelas dan sistimatis maka upaya membangun produk naik kelaspun akan dapat diwujudkan.

Seseorang berwirausaha tentunya berharap usahanya akan berjalan dan berkelanjutan. Hal ini memang tidaklah mudah dalam membangun bisnis yang berkelanjutan. Bagaimanapun juga wirausaha akan terus berkreasi dan berinovasi sehingga kepuasan pelanggan pun dapat diwujudkan. Artinya seorang wirausaha akan berpikir bahwa kepuasan pelanggan menjadi elemen penting yang utama dalam membangun bisnis yang berkelanjutan. Jadi masalah kepuasan pelanggan bukan hanya perusahaan besar saja yang terus meningkatkan diri dalam hal ini, tetapi wirausaha JAKPRENEURpun terus membangun dirinya agar kepuasan pelanggan dapat terwujud. Bisnis ada karena pelanggan (Ilias \& Shamsudin, 2020), organisasi yang berorientasi pada pelanggan akan mengutamakan tinggi untuk memenuhi kebutuhan dan keinginan pelanggan. Itulah sebabnya, organisasi melayani pelanggan sebagai detak jantung dalam organisasi. Tanpa pelanggan, organisasi tidak memiliki penghasilan dan mereka tidak dapat mempertahankan di industri. Untuk memastikan organisasi, tetap kompetitif, mereka perlu mengelola pelanggan mereka dengan baik dengan membuat mereka senang melakukan transaksi bisnis dengan mereka sehingga perwujudan kepuasan pelanggan menjadi utama. Kepuasan Pelanggan dengan mewujudkan kualitas produk, kemasan, promosi, pelayanan dan lainnya. Kepuasan pelanggan adalah hasil penting bagi organisasi bisnis oleh (Mokhtar \& Shamsudin, 2020). Pelanggan memainkan beberapa peran terhadap organisasi yang pertama adalah pelanggan mendorong pendapatan bisnis. Pasalnya, tanpa pelanggan, bisnis tidak memiliki apa pun untuk ditawarkan di mana mereka tidak mendapat imbalan apa pun bagi bisnis mereka untuk tetap bertahan di pasar sehingga membangun kepuasan akan berkelanjutan untuk bisnisnya.

Penelitian terdahulu (Purwoko, Haryana, \& Tamba, 2021) memaparkan bahwa kemasan berpengaruh signifikan terhadap kepuasan pelanggan, kemasan tidak berpengaruh signifikan terhadap loyalitas pelanggan, kualitas tidak berpengaruh signifikan terhadap kepuasan pelanggan, kualitas tidak berpengaruh signifikan terhadap loyalitas pelanggan. Hal ini (Saputra, Lewangka, \& Munir, 2020) bahwa promosi memiliki dampak positif dan tidak signifikan pada kepuasan konsumen. Kepuasan konsumen memiliki efek positif dan signifikan pada keputusan pembelian kembali. Kualitas produk secara langsung memiliki efek positif dan signifikan pada keputusan pembelian kembali. Promosi langsung positif dan tidak signifikan untuk membeli kembali keputusan.

Berdasarkan hasil penelitian di atas tentunya harus dapat mengelola promosi pengaruhnya terhadap kepuasan pelanggan, walaupun hasilnya tidak 
signifikan tentunya akan dapat menjungkat penjualan sehingga dikelola dengan baik promosi yang tepat dan akan dapat meningkatkan kepuasan pelanggan.

Penelitian ini merupakan perwujudan dalam kinerja wirausaha JAKPRENEUR Kecamatan Cipayung sebagai upaya meningkatkan penjualan dan perubahan agar lebih inovatif sehingga wirausaha JAKPRENEUR dapat naik kelas. Upayanya tentunya harus berkelanjutan dalam pendampingan sehingga kepuasan pelanggan produk-produk wirausaha JAKPRENEURpun dapat terwujud sehingga membangun lotalitas pelanggan. Peningkatan Kualitas Produk, Kemasan dan Promosi harus terus dilakukan sehingga kepuasan pelangganpun dapat terwujud.

JAKPRENEUR merupakan salah satu Kegiatan Strategis Daerah (KSD) Pemerintah Propinsi DKI Jakarta dengan berlandaskan pada Peraturan Gubernur No.2 Tahun 2020 yang merupakan penyempurnaan standarisasi kerja dalam Program OKE OCE yang dimulai Tahun 2018 dan Pengembangan Kewirausahaan Terpadu pada Tahun 2019.

\section{METODOLOGI}

\section{Pengembangan Model}

Mewujudkan kualitas produk memang tidaklah mudah karena harus melalui proses panjang untuk berulang kali mencoba sehingga produk yang kita hasilkan sesuai dengan pasar. Kualitas produk merupakan area vital karena keberlanjutan sebuah usaha adalah dalam produknya. Apabila produk tidak berkualitas maka sudah ditinggalkan konsumen. Apalagi kita pahami bahwa konsumen sudah cerdas dalam membeli dan sebagai wirausaha harus memahami bahwa kualitas produk akan berdampak pada kepuasan pelanggan dan berakhir akan keberlanjutan usahanya. Ini juga digunakan sebagai salah satu strategi diferensiasi produk oleh beberapa perusahaan terkemuka. Pemasaran harus menetapkan standar kualitas untuk produk perusahaan. Terus memverifikasi standar ini dan meningkatkannya sesuai kebutuhan; meningkatnya kecanggihan pasar adalah tugas penting dalam manajemen produk. Sebuah produk dengan tingkat yang lebih tinggi kualitasnya akan lebih tinggi kemampuannya memuaskan pelanggan. Artinya apa yang ada dalam produk tersebut akan berdampak pada kepuasan pelanggan. Kualitas yang baik akan menambah nilai dan kepuasan bagi pelanggan. Pemasar berperan membantu perusahaan untuk mendefinisikan dan memberikan produk berkualitas tinggi dengan menargetkan pelanggan agar loyal. Bagian Pemasaran mampu menerapkan tugasnya dengan memberikan masukan berhubungan dengan manajemen kualitas secara menyeluruh dan dampaknya pada kepuasan pelanggan. Apabila hal ini diterapkan dengan baik maka akan dicapai profitabilitas pelanggan dan perusahaan. Dengan mengelola yang lebih baik akan diperoleh keberlanjutan dalam usaha dan hal ini akan berdampak pada citra produk/ merek yang lebih berkualitas di dunia yang kompetitif ini (Singh, 2021). Kualitas produk dapat diukur berdasar kemudahan penggunaan, daya tahan, kejelasan fungsi, keragaman ukuran produk, dan lain-lain (Zeithalm, 1988; Kotler \& Keller, 2009).

H1: Kualitas Produk berpengaruh terhadap Kepuasan Pelanggan

UMKM merupakan utama untuk pertumbuhan ekonomi terhadap kinerja ekonomi Malaysia secara keseluruhan. Meskipun potensi ekonominya, usaha mikro pedesaan memiliki sejumlah kendala seperti rendahnya tingkat produktivitas, tidak konsisten pasokan bahan baku, tingkat produksi yang rendah dan tidak efisien, metode pemrosesan yang sudah ketinggalan zaman dan produk makanan dan kemasan produk, kebersihan dan sanitasi yang buruk praktek, kurangnya pengembangan produk dan strategi pemasaran. Kemasan merupakan 
hal yang penting dalam meningkatkan kepuasan pelanggan dan kinerja wirausaha di Malaysia (Norhaziah \& Noor, 2011). Berbicara kemasan bagi perusahaan besar memang sudah ada bagian khsusus yang mengelola kemasan, naum hal ini berbeda dengan wirausaha, terkadang kemasan tidak dipikirkan atau tidak sampai ke titik ini, sehingga produk yang dihasilkan apa adanya. Indikator-indikator kemasan antara lain sebagai berikut (Kotler \& Armstrong, 2012): 1) Desain kemasan; berkaitan dengan tampilan kemasan yaitu seberapa baik kemasan dari sebuah produk dapat menarik konsumen; 2) Mutu kemasan, yaitu berkaitan dengan kualitas fisik dan non fisik yang mampu mendatangkan kepercayaan konsumen sekaligus mengangkat citra diri konsumen sehingga konsumen tergerak melakukan pembelian produk yang dikemas; 3) Inovasi kemasan, yaitu yang berkaitan dengan tambahan ragam bentuk dan fungsi yang melekat pada kemasan.

H2: Kemasan berpengaruh terhadap Kepuasan Pelanggan

Pengaruh promosi terhadap kepuasan pelanggan menjadi perhatian wirausaha dan juga perusahaan-perusahaan besar karena apabila salah penempatan promosi maka bisa vatal, artinya wirausaha dan perusahaanpun harus memprioritaskan promosi dengan baik. Hal ini juga tergambar dengan perusahaan yang memang mengalokasikan dananya untuk promosi. Untuk hal ini wirausaha tentunya harus cerdas dalam melakukan promosi produknya, tidak harus mengeluarkan dana besar. Perusahaan yang sadar akan pentingnya promosi akan mengeluarkan anggaran untuk promosi, namun variasi terjadi di efek promosi penjualan berdasarkan daya tarik merek yang bersangkutan (Alvarez \& Jermann, 2006). Artinya promosi dijalankan, namun tidak diimbangi dengan penguatan daya Tarik merek dan faktor yang melingkupi sebuah produk. Promosi penjualan adalah alat berguna yang bertindak sebagai penguat permintaan yang tidak mempertahankan risiko yang terkait dengan produk baru. Perusahaan harus sadar bahwa tatanan produk yang dipromosikan harus sesuai dengan kapasitas produknya tanpa mengaitkan produk lainnya (Blayyberg \& Nelin, 1990). Hal yang berkenaan promosi yaitu (Tjiptono, 2008): 1). Periklanan adalah komunikasi menggunakan berbagai media untuk mengkomunikasikan sesuai kepada konsumen, yang bentuknya dapat berupa banner, poster, dan lain sebagainya. Perusahaan besar akan memanfaatkan media periklanan secara kontinyu baik di media televisi, youtube yang jangkauannya luas 2) Penjualan personal adalah interaksi langsung, komunikasi tatap muka antara penjual dengan pembeli untuk memperkenalkan produknya. Ini bisa digunakan wirausaha dalam mempromosikan produknya karena tidak membutuhkan biaya besar 3). Promosi penjualan yaitu kegiatan yang dilakukan sebagai upaya mempengaruhi kegiatan pengambilan keputusan pembelian, tujuannya untuk menarik pelanggan. 4). Hubungan masyarakat yang merupakan sebuah upaya komunikasi secara menyeluruh dalam rangka mempengaruhi perilaku konsumen. Promosi yang berkelanjutan sangat diperlukan bagi pengusaha baik pengusaha level kecil maupun besar. Demikian juga wirausaha harus melakukan promosi yang berkelanjutan dan pada tempat serta waktu yang tepat. Apalagi Kemasan memiliki pengaruh yang signifikan terhadap kepuasan pelanggan, tentunya harus diperhatikan dan menjadi prioritas (Purwoko, Haryana, \& Tamba, 2021). Walaupun untuk mewujudkan hal ini tidaklah mudah tetapi pengaruh yang signifikan ini akan menjadi pemikiran bagi wirausaha dalam meningkatkan kemasannya berdampak pada kepuasan pelanggan.

H3: Promosi berpengaruh terhadap Kepuasan Pelanggan 


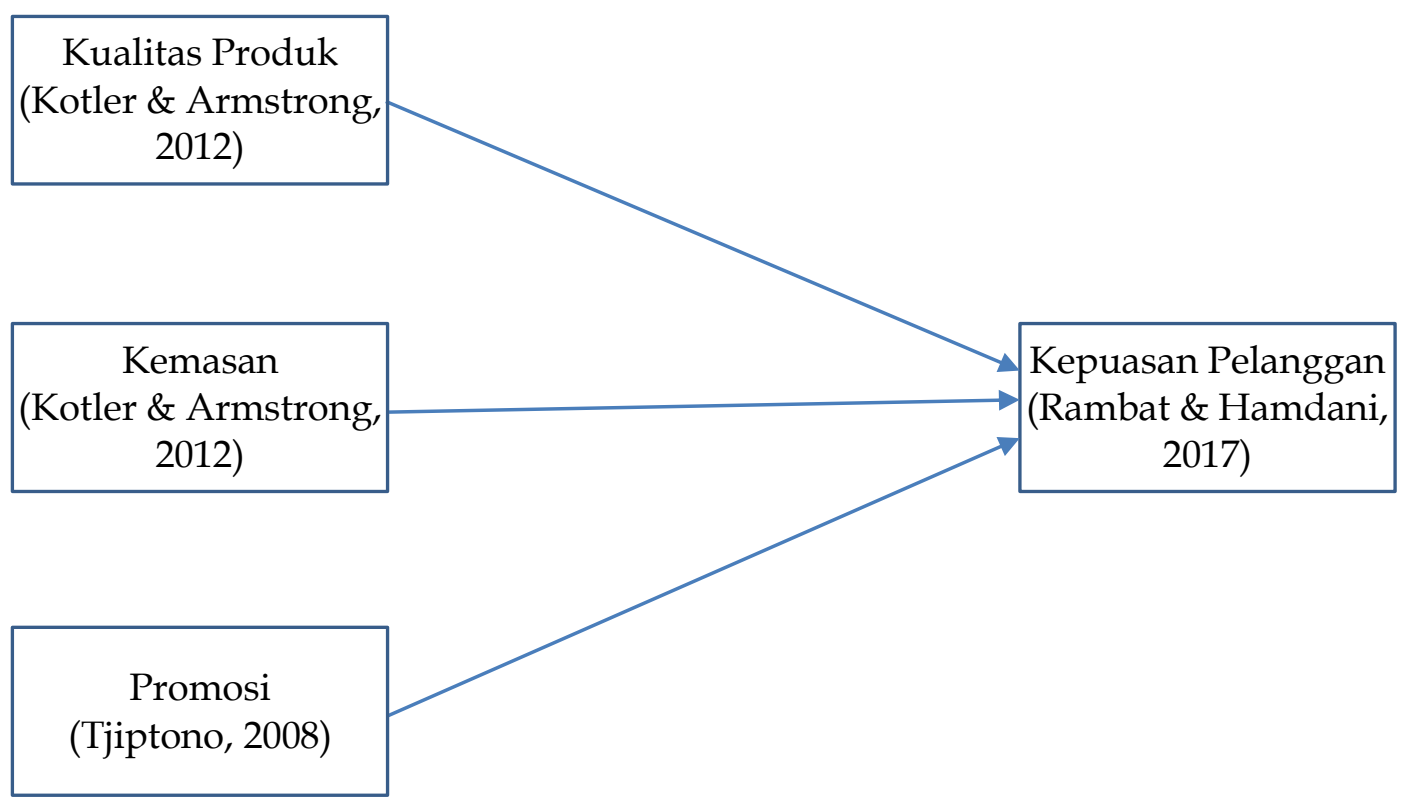

Sumber: Dikembangkan untuk Penelitian ini, 2021

Gambar 1. Kerangka Penelitian

Tabel 1. Operasionalisasi Variabel

\begin{tabular}{llll}
\hline \multicolumn{1}{c}{ Variabel } & \multicolumn{1}{c}{ Indikator } & Skala \\
\hline Variabel Kualitas Produk & - Kualitas & \\
(Kotler \& Armstrong, 2012) & - Percaya & Likert dan Ordinal \\
& - Manfaat & \\
\hline Variabel Kemasan & - Citra diri produk & Likert dan Ordinal \\
(Kotler \& Armstrong, 2012) & - Mutu & \\
& - Inovasi & \\
\hline Variabel Promosi & - Periklanan & \\
(Tjiptono, 2008) & - Penjualan Personal & \\
& - Promosi Penjualan & \\
\hline Variabel Kepuasan Pelanggan & - & Kubungan Masyarakat & \\
(Rambat \& Hamdani, 2017) & - Kualitas Produk & \\
& - & Emosional & \\
& - & Harga & \\
\hline
\end{tabular}

Sumber: Hasil Olahan, 2021

\section{Pengumpulan Data}

Tempat penelitian di Kecamatan Cipayung Jakarta Timur meliputi 8 (delapan) Kelurahan yaitu Setu, Bambu Apus, Cipayung, Pondok Rangon, Munjul,
Ceger, Cilangkap dan Lubang Buaya. Waktu Penelitian selama 4 bulan yaitu dari bulan yaitu Maret s.d Juni 2021

Populasi adalah pelanggan JAKPRENEUR di Kecamatan Cipayung Jakarta Timur. Sampel yang merupakan 
bagian dari populasi dalam hal ini adalah sekelompok pelanggan tertentu yang terpilih untuk mewakili pelanggan di obyek penelitian (Mulyanto \& Wulandari, 2010). Sampel dalam penelitian ini sejumlah 104 orang pelanggan dengan Teknik Insidental Sampling.

\section{Metode Analisis}

Metode analisis dalam penelitian ini menggunakan SPSS Versi 26 (Statistical Package for Social Science). Data diperoleh dari Penyebaran Kuesioner yang selanjutnya dilakukan Uji Kualitas Data berupa Uji Validitas dan Reliabilitas. Pedomannya dikatakan valid apabila nilai rhitung > rProduct Moment dengan n= 104 sedangkan pedoman dikatakan Reliabel apabila nilai Alphahitung > Alpha Ansoff 0,600 .

Tahap berikutnya, melakukan Uji Asumsi Klasik: 1). Uji Normalitas, dikatakan berdistribusi normal apabila nilai nilai Kolmogorov Smirnov (KS) dengan nilai Asym.Sig > 0,05; 2). Uji Heteroskedastisitas. Model regresi yang baik adalah yang homoskedastisitas atau tidak terjadi heteroskesdatisitas. Titik titik tidak membentuk sebuah pola yang mengumpulkan tetapi menyebar dari sumbu titik-titik plotnya menyebar di atas dan bawah angka nol pada sumbu Y.; 3). Uji Multikolinieritas. Uji Multikolinieritas adalah untuk menguji apakah model regresi ditemukan adanya korelasi (hubungan kuat antar variabel bebas. Model regresi yang baik seharusnya tidak terjadi korelasi di antara variabel bebas atau tidak terjadi gejala multikolinieritas. Pengambilan keputusan pada Uji Multikolinieritas berdasarkan Nilai Tolerance yaitu Jika nilai Tolerance lebih besar dari 0,10 maka artinya tidak terjadi Multikolinieritas dan Nilai Variance Inflation Factor (VIF) yaitu jika nilai VIF $<$ 0,10 maka artinya tidak terjadi multikolinieritas dalam model regresi.
Tahap berikutnya melakukan Uji Model. Uji model dilakukan dengan Analisis Koefisien Determinasi dan Uji F. Analisis Koefisien Determinasi merupakan suatu analisis atau pengujian untuk mengetahui pengaruh variabel bebas terhadap variabel terikat secara persentase. Sedangkan Uji F atau disebut juga Uji Anova merupakan pengaruh 2/lebih variabel bebas terhadap variable terikat secara signifikan dengan nilai Fhitung memiliki tingkat sign $<0,05$.

Terakhir melakukan Uji Hipotesis dan Regresi. Uji Hipotesis dengan Uji t yaitu pengujian satu variabel bebas terhadap satu variable terikat secara signifikansi dengan nilai thitung memiliki tingkat sign $<0,05$. Uji Regresi yaitu dengan membangun Persamaan Regresi berupa $Y$ $=a+b 1 X 1+b 2 X 2+b 3 X 3$.

\section{HASIL DAN PEMBAHASAN}

\section{Hasil Pengujian Validitas dan Reliabilitas}

Hasil pengujian validitas ternyata dari 10 butir pertanyaan pada variabel Kualitas Produk $\left(X_{1}\right)$ memiliki nilai $r_{\text {hitung }}>$ rProduct Moment 0,195 sehingga hasilnya valid dan dapat dijadikan instrumen penelitian selanjutnya. Sedangkan hasil pengujian reliabilitas berupa nilai $\alpha_{\text {hitung }}$ dari 10 butir pertanyaan memiliki nilai Cronbach alpha lebih besar dari pada nilai aAnsoff sebesar 0,600. Pada variabel Kemasan $\left(X_{2}\right)$ ada 10 butir pertanyaan diuji validitas. Berdasarkan pengujian ternyata nilai $r_{\text {hitung }}>$ rProduct Moment 0,195 sehingga kesimpulannya hasilnya valid. Pengujian reliabilitas hasilnya yaitu nilai $\alpha_{\text {hitung }}>$ aAnsoff sebesar 0,600, sehingga hasilnya reliability.

Hasil pengujian validitas ternyata dari 10 butir pertanyaan pada variabel Promosi $\left(\mathrm{X}_{3}\right)$ memiliki nilai $\mathrm{r}$ hitung $>$ rProduct Moment 0,195 sehingga hasilnya valid dan dapat dijadikan instrumen penelitian selanjutnya. Sedangkan hasil pengujian reliabilitas berupa nilai $\alpha_{\text {hitung }}$ dari 10 butir pertanyaan memiliki nilai Cronbach alpha 
lebih besar dari pada nilai aAnsoff sebesar 0,600 .

Pada variabel Kepuasan Pelanggan (Y) berdasarkan hasil pengujian validitas dan reliabilitas hasilnya valid dan reliabel karena nilai nilai $\mathrm{r}_{\text {hitung }}>$ rProduct Moment 0,195 dan diuji reliabilitas nilai a aitung $>$ aAnsoff sebesar 0,600.

\section{Uji Asumsi Klasik}

\section{Uji Asumsi Normalitas}

Nilai Kualitas Produk berdistribusi normal karena nilai Kolmogorov Smirnov (KS) sebesar 1,152 dengan nilai Asym.Sig 0,141. Sedangkan Nilai KS Kemasan sebesar 1,007 dengan nilai Asym.Sig 0,263. Nilai KS pada Promosi sebesar 1,221 dengan nilai Asym.Sig 01,101 dan Kepuasan Pelanggan sebesar 1,090 dengan nilai Asym.Sig 0,186. Hasil Asym. Signya melebihi 0,05 yang berarti hasilnya berdistribusi normal.

\section{Uji Asumsi Heteroskedastisitas}

Heteroskedastisitas diperlukan untuk memastikan bahwa dalam model regresi terjadi kesamaan varian residual pengamatan satu dengan lainnya. Terpenuhinya asumsi klasik ini jika terjadi homokedastisitas yaitu suatu kondisi dimana varian dari berbagai pengamatan tetap. Deteksi tidak adanya heteroskedastisitas dilakukan secara grafik plot yang membandingkan nilai prediksi dari variabel terikat (ZPRED) terhadap nilai residualnya (ZRESID). Apabila grafik yang terbentuk membentuk pola tertentu yang konstan maka telah terjadi heteroskedastisitas. Asumsi ini terpenuhi manakala titik-titik residual pada grafik yang dihasilkan tersebar acak diatas dan dibawah nilai origin sumbu $\mathrm{Y}$ atau tidak ada pola tertentu yang sifatnya mengumpul, maka dapat disimpulkan bahwa tidak terjadi masalah heteroskedastisitas. Model regresi yang baik adalah plot yang mengindikasikan homokedastisitas atau tidak terjadi heteroskedastisitas (Santoso, 2021). Intinya dalam pengujian heteroskedastisitas tidak terjadi pengumpulan simbol titik-titik yang dibangun dari variabel yang diteliti. Pada penelitian ini hasilnya tidak terjadi heteroskedastisitas pada model yaitu pengumpulan titik-titik simbol variabel yang diteliti, sehingga model persamaan regresi yang dibangun layak untuk memprediksi variabel Y (Kepuasan Pelanggan) atas dasar masukan variabel independen yaitu variabel $\mathrm{X}_{1}$ (Kualitas Produk), variabel $X_{2}$ (Kemasan) dan variabel $\mathrm{X}_{3}$ (Promosi).

\section{Uji Multikolinieritas}

Hasil terbesar pada variabel $X_{1}$ (Kualitas Produk) yang mempunyai korelasi cukup dengan variabel $\mathrm{X}_{2}$ (Kemasan) yaitu tingkat korelasinya sebesar -0,462 atau $-46,2 \%$, oleh karena korelasi ini masih di bawah 95\%, maka tidak terjadi multikolinieritas.

\section{Uji Model}

Uji Model dilakukan dengan Uji Koefisien Determinasi dan Uji F. Hasil Uji Koesfisien Determinasi atau nilai RSquare yaitu pengaruh Kualitas Produk, Kemasan dan Promosi terhadap Kepuasan Pelanggan sebesar 0,962 atau $96,2 \%$ dan sisanya sebesar 3,8\% dipengaruhi di luar variabel yang diteliti. Sedangkan nilai Uji F yaitu Fhitung sebesar 855,099 dengan memiliki nilai sign sebesar 0,000 yang berarti hasilnya signifikan karena nilai sign $<0.05$.

\section{Uji Hipotesis}

Persamaan regresi dalam penelitian ini yaitu: $Y=1,144+0,408 X_{1}+0,218 X_{2}$ $+0,361 X_{3}$. Nilai koefisien regresi masingmasing variabel positif dimana koefisien regresi $X_{1} Y$ sebesar 0,408 , nilai $X_{2} Y$ sebesar 0,218 dan nilai $X_{3} Y$ sebesar 0,361 . Kenaikan $\mathrm{X}$ akan diikuti oleh kenaikan $\mathrm{Y}$.

Tabel 2 Hasil Uji t

\begin{tabular}{cccc}
\hline Variabel & thitung $_{\text {hign }}$ & Hasil \\
\hline $\mathrm{X}_{1}$ & 8,313 & 0,000 & Signifikan \\
\hline
\end{tabular}




\begin{tabular}{llll}
\hline $\mathrm{X}_{2}$ & 4,800 & 0,000 & Signifikan \\
$\mathrm{X}_{3}$ & 7,572 & 0,000 & Signifikan \\
\hline
\end{tabular}

Sumber: Hasil Penelitian, 2021

Hipotesis pertama pada Variabel Kualitas Produk terhadap Kepuasan Pelanggan yaitu nilai thitung $X_{1} Y$ sebesar 8,313 memiliki tingkat signifikansi 0,000 berarti hasil signifikan karena nilai sig. di bawah 0,05. Hipotesis ke 2 bahwa Variabel Kemasan berpengaruh secara signifikan terhadap Kepuasan Pelanggan, hal ini dibuktikan dengan hasil $\mathrm{Uji} \mathrm{t}$ yaitu $\mathrm{t}_{\text {hitung }}$ $\mathrm{X}_{2} \mathrm{Y}$ sebesar 4,800 memiliki tingkat signifikansi 0,000 berarti hasil signifikan karena nilai sign di bawah 0,05. Hasil hipotesis ke 3 pada variabel Promosi yaitu hasilnya signifikan, hal ini dibuktikan dengan hasil Uji $t$ yaitu $t_{\text {hitung }} \mathrm{X}_{3} \mathrm{Y}$ sebesar 7,572 memiliki tingkat signifikansi 0,000 berarti hasil signifikan karena nilai sign di bawah 0,05.

\section{PEMBAHASAN}

\section{Pengaruh Kualitas Produk terhadap Kepuasan Pelanggan}

Kualitas Produk terhadap Kepuasan Pelanggan hasilnya signifikan. Nilai regresinya sebesar 0,408 yang artinya pengaruh Kualitas Produk terhadap Kepuasan Pelanggan sebesar 0,408. Hal ini diperkuat temuan yang menyatakan kualitas yang sangat baik perusahaan dapat mempertahankan citra produk atau merek yang cerah dalam pikiran pelanggan di dunia yang kompetitif (Singh, 2021). Hal ini diperkuat temuan penelitian yang mengungkap adanya pengaruh kualitas produk pada kepuasan pelanggan (Jannah, Mappatompo, \& Haanurat, 2019).

Berdasarkan hasil penelitian di atas tentunya menjadi masukan bagi wirausaha JAKPRENEUR dalam membangun kualitas produk berupa kualitas, kepercayaan, manfaat dan citra produk harus terus ditingkatkan sehingga menjadi lebih baik dan akan dapat mewujudkan kepuasan pelanggan yang berkelanjutan.

\section{Pengaruh Kemasan terhadap Kepuasan Pelanggan}

Kemasan secara signifikan mempengaruhi Kepuasan Pelanggan. Hal ini diperkuat dengan hasil penelitian (Gammudi, Salim, \& Sabil, 2016) yang menemukan bahwa kemasan berpengaruh terhadap kepuasan pelanggan. Desain kemasan dapat memperkuat persepsi konsumen bahwa suatu produk baru dan menarik, yang akan mempengaruhi keputusan pembelian secara langsung, dan kepuasan secara tidak langsung.

Hasil ini tentunya menjadi rujukan bagi wirausaha JAKPRENEUR dalam menata kemasan produknya sehingga kepuasan pelanggan akan berdampak pada loyalitas terhadap produk tersebut. Tentunya desain harus dijaga, ditingkatkan keamanan dan Kesehatan untuk produk tersebut selain itu menarik selain itu mutu produk harus dijaga sehingga kemasan yang dibuat harus menjaga mutu produk sampai ke tangan pelanggan. Walaupun berupa kemasan naun inovasi juga harus dilakukan secara berkelanjutan dalam tatanan yang menarik dan inovatif.

\section{Pengaruh Promosi terhadap Kepuasan Pelanggan}

Promosi berpengaruh secara signifikan terhadap kepuasan pelanggan. Hal ini diperkuat dengan temuan terdahulu (Jean \& Yazdanifard, 2015) bahwa promosi berpotensi membantu para pemasar mencapai keuntungan jangka panjang melalui kegiatan mengkomunikasikan perusahaan untuk mempengaruhi kepuasan konsumen sehingga pelanggan berkembang.

Promosi berpengaruh terhadap Kepuasan Pelanggan (Schultz \& Block, 2014). Namun berbeda dengan hasil penelitian lain (Saputra, Lewangka, \& Munir, 2020) bahwa Promosi memiliki dampak positif dan tidak signifikan pada kepuasan konsumen. 
Berdasarkan hasil penelitian di atas tentunya JAKPRENEUR akan dapat meningkatkan promosinya dengan berbagai media, walaupun ada hasil penelitian yang menyatakan tidak signifikan pengaruh promosi terhadap kepuasan pelanggan, namun ini bukan menjadi referensi secara umum dalam meningkatkan kepuasan pelanggan yang berkelanjutan. JAKPRENEUR memiliki kesempatan untuk promosi luas ke berbagai media berupa periklanan baik berbayar maupun non berbayar, penjualan secara personal yaitu one to one sehingga JAKPRENEUR akan semakin memahami pelanggan dan kepuasan pelangganpun dapat terwujud. Promosi penjualan harus terus dilakukan dan tentunya berinteraksi, berhubungan dengan masyarakat sehingga tercipta saling mengenal, memahami personal dan produknya yang akhirnya membangun kepuasan pelanggan yang prima.

\section{KESIMPULAN}

Kualitas Produk, Kemasan dan Promosi berpengaruh positif secara signifikan terhadap Kepuasan Pelanggan. Hasil penelitian ini mendukung hipotesis penelitian.

Pembinaan harus terus dilakukan dan berkelanjutan untuk para wirausaha JAKPRENEUR di Kecamatan Cipayung Jakarta Timur karena membangun kualitas produk, kemasan dan promosi yang tepat akan dapat mewujudkan kepuasan pelanggan sehingga menjadi loyal terhadap produk JAKPRENEUR sehingga Produk akan Naik Kelas baik kualitas produk, kemasan, cita rasa, inovasi maupun pemasarannya.

Penelitian ini diharapkan dapat menjadi rujukan penelitian selanjutnya yaitu dikembangkan lebih luas bukan sekedar variabel yang diteliti ini.

\section{DAFTAR PUSTAKA}

Alvarez, F., \& Jermann, U. J. (2006). Using Asset Prices to Measure the Persistence of the Marginal Utility of Wealth. The Econometric Sociaetystable, 73(6), 1977-2016.

Blayyberg, R., \& Nelin, A. (1990). Sales Promotion: Concepts, Methods and Strategies. New Jersey: Prentice Hall .

Gammudi, A. K., Salim, U., \& Sabil, A. (2016). The Effect of Packaging Satisfaction and Image on Customer Loyalty oh The El Rayhan Company. Center for Indonesia Accounting and Management Research, 24(1).

Ilias, S., \& Shamsudin, M. F. (2020). Customer Satisfaction and Business Growth. Journal of Undergraduate Social Science E Technology, 2(2). Retrieved from Vol. 2 No. 2 (2020): Vol 2.2.2020.

Jannah, R., Mappatompo, A., \& Haanurat, I. (2019). The Influence of Product Quality and Promotion on Customer Satisfaction and Its Impact on Customer Loyalty PT. Mahakarya Sejahtera Indonesia. Proceeding of The 3rd International Conference on Accounting, Business E Economics (UII-ICABE 2019). Yogyakarta: UII.

Jean, W. A., \& Yazdanifard, R. (2015). The Review of how Sales Promotion Change the Consumer's Perception and Their Purchasing Behavior, Help College Of Arts And Technology, Malaysia. Global Journal of Management and Business Research: E Marketing, 15(5).

Kotler, P., \& Armstrong, G. (2012). Principles of Marketing. New Jersey: Prentice Hall.

Kotler, P., \& Keller, K. L. (2009). Manajemen Pemasaran Jilid 1 Edisi 13. Jakarta: Erlangga.

Mokhtar, M. R., \& Shamsudin, M. F. (2020). How to keep up with customer? Universiti Kuala Lumpur. Journal of Postgraduate Current Business Research (JPCBR), 5(1).

Mulyanto, H., \& Wulandari, A. (2010). Penelitian: Metode \& Analisis. Semarang: CV Agung. 
Norhaziah, \& Noor, M. (2011). The Importance of Micro Financing to the Microenterprises Development in Malaysia's Experience. 7(12), 226.

Purwoko, S., Haryana, A., \& Tamba, M. (2021). Pengaruh Kemasan, Kualitas Dan Harga Produk Susu Terhadap Kepuasan Dan Loyalitas Pelanggan PT. Dwimitra Usaha Global. Jurnal Administrasi Dan Manajemen. Retrieved from http://ejournal.urindo.ac.id/index.php/administrasimanajemen/index

Rambat, L., \& Hamdani. (2017). Manajemen Pemasaran Jasa. Jakarta: Salemba Empat.

Santoso, S. (2021). Panduan Lengkap SPSS 26. Jakarta: PT Gramedia.

Saputra, I., Lewangka, O., \& Munir, A. R. (2020). The Influence of Product Quality and Promotion on Repurchase Pertamax through Consumer Satisfaction in Makassar City, Universitas Hasanudin, Makasar. Vol 2 No 2 (2020): Hasanuddin Journal of Business. Hasanuddin Journal of Business, 2(2).

Schultz, D. E., \& Block, M. P. (2014). Brand Preference Being Challenged. Journal of Brand Management.

Singh, M. (2021). Marketing Mix of 4P'S for Competitive Advantage. IOSR Journal of Business and Management (IOSRJBM), 3, 40 - 45.

Tjiptono, F. (2008). Strategi Pemasaran. Yogyakarta: Penerbit Andi. 